\title{
Altered decidual leucocyte populations in the placental bed in pre-eclampsia and foetal growth restriction: a comparison with late normal pregnancy
}

\author{
Paula J Williams, Judith N Bulmer, Roger F Searle, Barbara A Innes and Stephen C Robson \\ Institute of Cellular Medicine, Newcastle University, 3rd Floor, William Leech Building, Newcastle-upon-Tyne, \\ Tyne and Wear NE2 4HH, UK \\ Correspondence should be addressed to J N Bulmer; Email: j.n.bulmer@ncl.ac.uk
}

\begin{abstract}
Alterations in the balance of leucocyte populations in uterine decidua may lead to the generation of an unfavourable cytokine environment that is associated with unsuccessful pregnancy. Single and double immunohistochemical labelling was used to examine leucocyte populations in decidua from normal third trimester, foetal growth-restricted and pre-eclamptic pregnancies. Placental bed biopsies from 12 women undergoing elective Caesarean section with no hypertension or foetal growth restriction (FGR), 8 women with FGR without maternal hypertension and 12 women with pre-eclampsia (PE) were used to quantify decidual CD56 + uterine NK cells, CD14 + macrophages, CD3 + T-lymphocytes and CD8 + lymphocytes. CD3 + CD56 +, CD8+CD56+ and CD161 + CD3 + double-labelled cells in decidua were compared in PE and control decidua. Decidual CD3 + T-lymphocytes $(P<0.01), C D 8+$ cytotoxic T-lymphocytes $(P<0.05)$, CD14 + macrophages $(P<0.0001)$ and CD56 + uterine natural killer $($ uNK $)$ cells $(P=0.01)$ were decreased in placental bed biopsies from women with PE compared with control third trimester decidua. By contrast, only CD56 + UNK cells were decreased in FGR decidua $(P<0.05)$. Double-positive CD8 + CD56 + cells were also decreased in PE compared with control third trimester decidua $(P<0.05)$. The reduction in specific leucocyte subset numbers in PE and uNK cells in FGR suggests that altered local cytokine balance may be important in defective trophoblast invasion and spiral artery transformation in these pathological pregnancies.

Reproduction (2009) 138 177-184
\end{abstract}

\section{Introduction}

Following implantation, the decidualised endometrium, a tissue containing a large population of leucocytes (King \& Loke 1991, Stallmach et al. 1995), is rapidly infiltrated by foetally derived extravillous trophoblast cells (EVT; Kurman et al. 1984, Yeh et al. 1991), which express the paternally derived non-self HLA antigens, HLA-G, HLA-E and HLA-C (Houlihan et al. 1995, Hutter et al. 1996, King et al. 1996). In normal pregnancy, 30-40\% of decidual stromal cells are leucocytes (Bulmer et al. 1991); in the first trimester, uterine natural killer (UNK) cells account for up to $70 \%$, macrophages up to $30 \%$ (Bulmer et al. 1988) and T-lymphocytes fewer than 20\% (Bulmer et al. 1991) of the total leucocyte population (Bulmer et al. 1991, King \& Loke 1991, Klentzeris et al. 1992). In contrast to first trimester decidua, third trimester decidua has been the subject of less research. Haller et al. (1993) reported an increase in CD3 + cells and a decrease in CD56 + (also known as $\mathrm{NCAM1+)}$ cells in third trimester compared with first trimester decidua, while Vargas et al. (1993) found an increase in CD16+ lymphocytes at term, contrasting with low CD16 + cell numbers in first trimester decidua.

The large number of uNK cells found in early pregnant decidua may reflect a role in spiral artery remodelling. Following implantation, trophoblast cells invade the lumen and wall of the spiral arteries, replacing the musculoelastic media of the arterial wall with a fibrinoid matrix and leading to increased placental blood flow (Pijnenborg et al. 1981). Spiral artery remodelling has previously been considered to be a trophoblastdependent process, but studies of human decidua have suggested that at least some remodelling precedes and occurs independently of interactions with EVT (Craven et al. 1998, Pijnenborg et al. 2006). In mice, this trophoblast-independent mechanism appears to be mediated by uNK cells (Ashkar et al. 2000); reconstitution with bone marrow from severe combined immunodeficient mice (deficient in T and B cells) largely corrected the spiral artery defects and decidual abnormalities (Guimond et al. 1998), implicating uNK 
deficiency as the primary cause of the pathology. We have recently reported that uNK cells are a prominent source of angiogenic growth factors in the placental bed during early human pregnancy (Lash et al. 2006a), supporting the suggestion that uNK cells play a role in spiral artery remodelling.

Failure of trophoblast invasion and spiral artery remodelling has been associated with the development of both pre-eclampsia (PE) and foetal growth restriction (FGR) in the absence of maternal hypertension (Khong et al. 1986, Pijnenborg et al. 1991). In PE, reduced placental perfusion is associated with endothelial dysfunction and FGR leading to significant maternal and perinatal morbidity and mortality. Studies of human decidual leucocyte populations in PE and FGR are limited. Khong (1987) reported no differences in placental bed and non-placental bed leucocyte populations in PE compared with normal-term pregnant controls while Stallmach et al. (1999) reported an increase in CD8 $+\mathrm{T}$ cells and CD56 + uNK cells in decidua from women with PE. These observations were confirmed in a flow cytometric study, CD56 + cells also showing an altered phenotype with a shift from the CD16-CD56+ to the more cytotoxic CD16+CD56+ phenotype (Wilczynski et al. 2003). By contrast, Eide et al. (2006) noted a reduction in the proportion of leucocytes accounted for by CD56 + NK cells in decidua from pregnancies complicated with FGR with or without PE compared with control samples. Increased macrophage numbers both around and within myometrial spiral arteries and in the superficial decidua have been reported in pre-eclamptic women (Reister et al. 1999, Lockwood et al. 2006), leading to the suggestion that macrophage-induced apoptosis may be responsible for preventing EVT invasion of the spiral arteries (Reister et al. 2001). However, other groups have reported no differences or even reduced decidual macrophage numbers in PE (Burk et al. 2001, Redline 2001, Kim et al. 2007). Overall, therefore, the precise composition of decidual leucocytes in pregnancies complicated by PE and FGR remains controversial and unclear. This may in part be due to the different sources of decidual tissue investigated in these studies either obtained by vacuum suction of the placental bed after delivery (Eide et al. 2006), attached to the placenta delivered by Caesarean section (Burk et al. 2001, Wilczynski et al. 2003, Lockwood et al. 2006) or from placental bed biopsies (Reister et al. 1999, Stallmach et al. 1999, Kim et al. 2007).

The aim of this study was to use single and double immunohistochemical labelling to quantify and compare the major leucocyte populations (CD3+, $\mathrm{CD} 8+, \mathrm{CD} 14+$ and CD56+) in placental bed decidua from normal third trimester pregnancy and pregnancies complicated with PE or FGR.

\section{Results}

\section{Pre-eclampsia}

\section{Single immunohistochemical labelling}

The three major leucocyte populations identified in normal third trimester decidua were also present in pregnancies complicated by PE. The numbers of all cell types were reduced in PE compared with third trimester controls (Figs 1 and 2); CD3: PE $20.4 \pm 1.9$ versus controls $40.3 \pm 6.7$; $P<0.01 ; C D 56: 18.3 \pm 1.9$ vs $29.0 \pm 3.3 ; P=0.01 ; C D 14$ : $8.3 \pm 0.7$ vs $17.3 \pm 1.2 ; P<0.0001$. In common with the results for $\mathrm{CD} 3$, the numbers of $\mathrm{CD} 8+$ lymphocytes were also reduced in $\mathrm{PE}$ compared with third trimester controls $(19.4 \pm 2.6$ vs $34.8 \pm 5.5 ; P<0.05)$.

\section{Double immunohistochemical labelling}

Small populations of CD3 + CD56+, CD161+ (also known as KLRB1C+) CD3 + and CD8+CD56+ cells were identified in both control third trimester pregnancy and PE decidua. No differences were found in the CD3 + CD56+ and CD161+CD3 + cell populations between the two study groups (Table 1). By contrast, numbers of $\mathrm{CD} 8+\mathrm{CD} 56+$ double-labelled cells were reduced in PE $(0.8 \pm 0.3)$ compared with control third trimester samples $(2.6 \pm 0.90, P<0.05)$.

\section{Foetal growth restriction}

In FGR without maternal hypertension, there was a similar reduction in the numbers of the three main leucocyte types (Fig. 1; CD3: 24.0 \pm 2.0 ; CD56: 14.1 \pm 2.7 ; CD14: $12.0 \pm 0.5)$ compared with control decidua. This reduction was, however, only significant for CD56+ uNK cells $(P<0.05)$, reductions in $\mathrm{CD} 3+(P=0.07)$ and $\mathrm{CD} 14+(P=0.06)$ just failing to reach statistical significance.

No significant differences were identified between decidual leucocyte populations in PE and FGR.

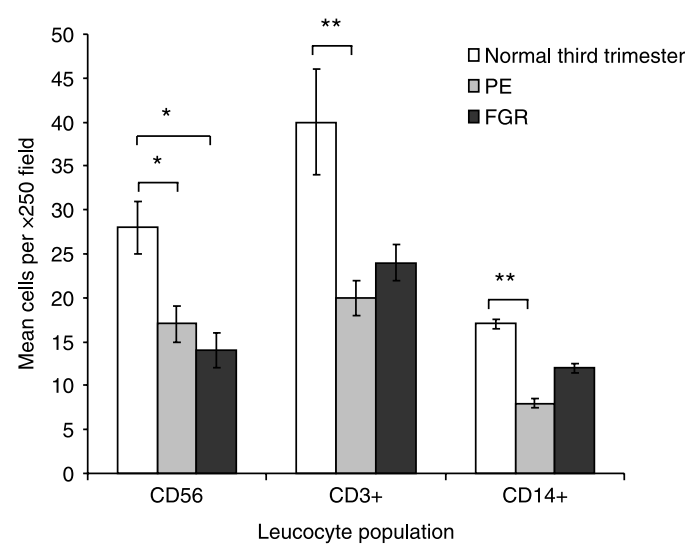

Figure 1 Decidual leucocyte numbers in FGR, PE and normal third trimester pregnancies. Data are expressed as mean cell count per $\times 250$ field and S.E.M. of multiple observations. ${ }^{*} P<0.05,{ }^{* *} P<0.001$. 

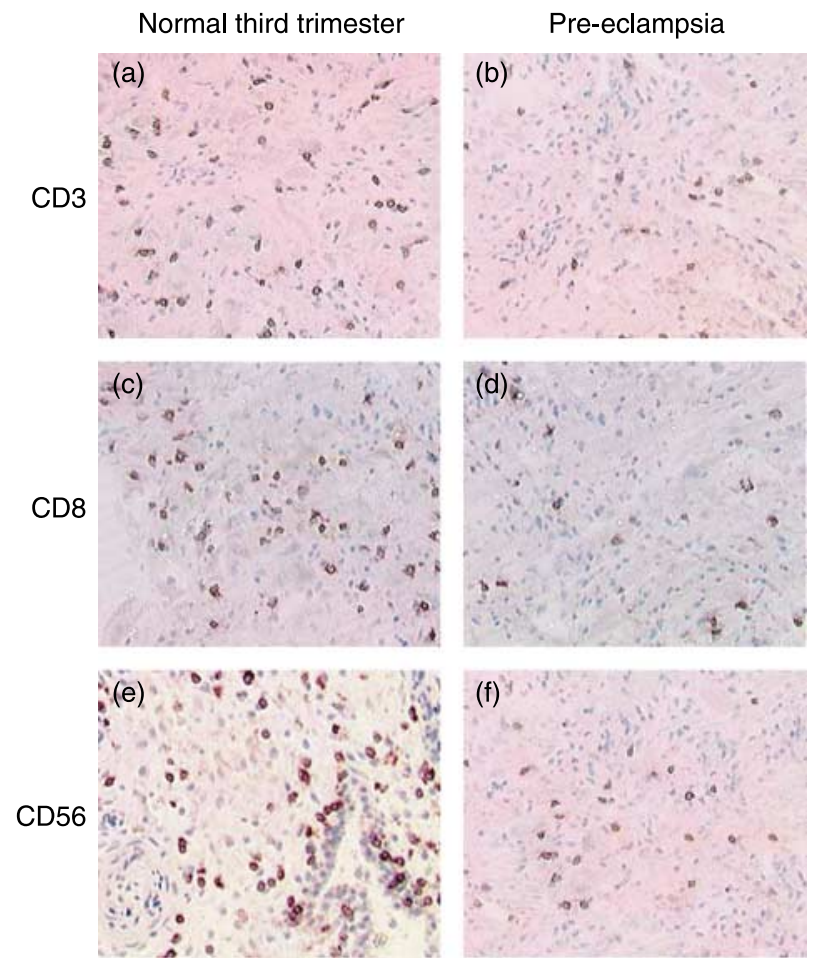

Figure 2 Photomicrograph of control third trimester (a, c and e) and $\mathrm{PE}(\mathrm{b}, \mathrm{d}$ and $\mathrm{f}$ ) placental bed decidua immunostained using an avidin-biotin peroxidase technique for CD3 (a and b) CD8 (c and d) and CD56 (e and f). Positive cells appear brown. Note reduction in all cell populations in pre-eclampsia compared with control third trimester samples. Magnification $\times 200$.

\section{Discussion}

Characterisation of decidual leucocyte populations in pregnancies complicated by PE or FGR may allow insights into the pathogenesis of these disorders. In the present study, all leucocyte populations present in normal late pregnancy decidua were identified in decidua from women with PE or FGR. However, in decidua from women with PE, T lymphocytes, UNK cells and macrophages were all reduced in number, while in pregnancies complicated by FGR only the reduction in uNK cell numbers was statistically significant.

The altered leucocyte subset cell numbers observed in PE compared with third trimester controls may reflect

Table 1 Comparison of CD3/CD56, CD8/CD56 and CD161/CD3 double labelling between pre-eclampsia (PE) and normal third trimester decidua.

\begin{tabular}{lccc}
\hline mAb & $\begin{array}{l}\text { Control third } \\
\text { trimester }\end{array}$ & Pre-eclampsia & $\boldsymbol{P}$ value \\
\hline CD3/CD56 & $1.27 \pm 0.27^{\mathrm{a}}$ & $1.50 \pm 0.26$ & 0.55 \\
$\mathrm{CD} 8 / \mathrm{CD} 56$ & $2.56 \pm 0.90$ & $0.75 \pm 0.25$ & 0.04 \\
CD161/CD3 & $5.70 \pm 0.52$ & $4.91 \pm 0.65$ & 0.36
\end{tabular}

${ }^{\mathrm{a}}$ Numbers represent mean number of positive cells per $\times 250$ field \pm S.E.M. either a reduction in leucocyte infiltration or perturbed leucocyte composition. However, the relative proportion of each of the leucocyte subset cell populations did not alter between either PE or FGR and third trimester controls (control: 33\% CD56, 47\% CD3 and 20\% CD14; PE: $38 \%$ CD56, 44\% CD3 and 18\% CD14; FGR: 28\% CD56, 48\% CD3 and 24\% CD14). Therefore, the most likely explanation for the reduced leucocyte subset cell numbers noted in PE in the current study is that there is an overall reduction in leucocyte infiltration into the decidua of these women. Whether the decrease in decidual leucocytes is a cause or effect of PE cannot be determined.

The results indicate that there may be a common pathogenesis between PE and FGR, and this is the work that needs further investigation. The decreased numbers of CD56 + cells in both PE and FGR may be involved in decreased vascular adaptation to pregnancy during placentation. The lack of significant differences between control and FGR for CD3 and CD14 positive cells may reflect the smaller subject group of FGR, as numbers of these cells showed a trend for reduction. A possible limitation of the study is that placental bed biopsies sample only a small area of the placental bed and may not be representative of the whole area. The distribution of leucocytes in both PE and controls, however, were consistent and provided no evidence for local variations.

In contrast to the decidual leucocyte composition in early normal pregnancy (Bulmer et al. 1991), CD3 + T cells predominated in third trimester decidua, with CD14 + macrophages and CD56+ uNK cells also present in substantial numbers. The presence of high numbers of CD56+ uNK cells in late pregnancy was striking as others have reported that CD56 + uNK cells decline after the first trimester and are virtually absent at term (Haller et al. 1993, Saito 2000). The present findings are, however, in agreement with the view that uNK cells are present at term (Sindram-Trujillo et al. 2003) but that their numbers are maximal during the period of trophoblast invasion and spiral artery remodelling that is characteristic of the first 20 weeks of pregnancy.

The observation of reduced $\mathrm{UNK}$ cell numbers in PE and FGR concurs with a recent report of reduced UNK cells in pregnancies complicated by FGR with or without PE (Eide et al. 2006); it should be noted that the PE study group in this study had growth-restricted babies. However, the findings contrast with those of Stallmach et al. (1999) and Bachmayer et al. (2006) who reported increased numbers of CD56+ cells in PE decidua compared with controls. In the absence of information on the FGR status of the PE study groups in these latter studies, use of placental bed biopsy and the avidinbiotin method, which is more sensitive than the PAP method used by Stallmach et al. (1999), may also partly account for the differences in uNK cell numbers. Reduction in CD56 + leucocyte numbers in PE with 
FGR and FGR uncomplicated by PE may be important in the pathogenesis of these conditions; failure of spiral artery 'transformation' occurs in the first half of pregnancy, long before clinical presentation (Brosens \& Renaer 1972). In murine pregnancy, spiral artery remodelling appears to be initiated by an uNK celldependent mechanism that is mediated, at least in part, by IFNG (Ashkar et al. 2000). Furthermore, IFNG induces nitric oxide synthase (NOS) activity, leading to the production of NO (Nunokawa \& Tanaka 1992). As well as being a powerful vasodilator, $\mathrm{NO}$ inhibits proliferation of rat vascular smooth muscle cells and chronic inhibition of NOS induces hypertension and FGR in animal models (Yallampalli \& Garfield 1993). A reduction in uNK cell numbers may also contribute to deficient spiral artery remodelling due to reduced production of angiogenic growth factors including vascular endothelial growth factor (VEGFA), angiopoietin-2 (ANGPT2) and placenta growth factor (PGF; Sharkey et al. 1993, Li et al. 2001, Lash et al. 2006a). Thus, reduction in the number of uNK cells could set up a cascade of events leading to altered trophoblast invasion and vascular remodelling (Hanna et al. 2006), ultimately resulting or contributing to vasoconstriction and PE or FGR in later pregnancy.

The reduction in $\mathrm{CD} 14+$ cell numbers in $\mathrm{PE}$ is consistent with a flow cytometric study (Burk et al. 2001) but conflicts with other immunohistochemical reports (Reister et al. 1999, Wilczynski et al. 2003, Lockwood et al. 2006, Kim et al. 2007). In common with Burk et al. (2001), we identified placental bed macrophages by CD14 immunopositivity specific for the endotoxin receptor expressed by macrophages, whereas others (Reister et al. 1999, Lockwood et al. 2006) used an antibody against CD68, which reacts with lysosomeassociated proteins and is a marker of phagocytic cells (Saito et al. 1991). Reister et al. (1999) also focused on macrophage numbers around myometrial spiral arteries while in the present study leucocyte populations were quantified in decidua basalis. Lockwood et al. (2006) described numerous focally clustered CD68 + cells in superficial decidua attached to the delivered placenta and noted that their distribution in controls varied widely, ranging from absent to sparse to numerous. The discrepancy in findings between studies may also partly reflect the difference sources of decidual tissue. Recently, Kim et al. (2007) have reported the presence of CD14-/CD68+ and CD14+/CD68+ cells in the placental bed of women with PE and preterm labour. Interestingly, CD14-/CD68 + cells predominated in the decidua while the reverse was found in the superficial myometrium. CD14 negative macrophages, as well as having reduced phagocytic activity, do not produce key cytokines known to regulate trophoblast invasion e.g. transforming growth factor- $\beta$ (TGFB) and TNF (Smythies et al. 2005). As with uNK cells, the reduced number of decidual macrophages may contribute to a local reduction in $\mathrm{NO}$ in PE (Haddad et al. 1995).

In addition to vascular remodelling, decidual leucocytes may also regulate EVT invasion. In human pregnancy, uNK cells produce significant amounts of IFNG (Saito et al. 1993) and the receptor for IFNG is present on EVT (Hampson et al. 1993) suggesting that IFNG could be involved in invasion. Reports have both supported and refuted a direct role for IFNG in regulation of EVT behaviour. We have recently demonstrated that IFNG regulates EVT invasion via mechanisms dependent on increased EVT apoptosis as well as decreased protease activity (Lash et al. 2006b). By contrast, a report examining EVT column formation and migration found IFNG to only partially regulate EVT (Hu et al. 2006). TNFA-related apoptosis inducing ligand (TNFSF10), expressed by decidual macrophages and $\mathrm{T}$ cells, has been shown to have stimulatory effects on trophoblast, increasing trophoblast invasion and migration and also inducing activation of insulin-like growth factor II and matrix metalloproteinase I genes, which are also involved in successful placentation (Phillips et al. 1999). Reduced numbers of decidual macrophages and $T$ cells in PE may thus lead to decreased levels of TNFSF10 expression thereby leading to a reduction in trophoblast invasion and perturbed placental function.

Representing the smallest immune cell population in first trimester human decidua, T lymphocytes have been the subject of little research. One of the major functions of CD3 + and CD8 + T-lymphocytes in decidua is likely to be cytokine production. The reduced levels of $\mathrm{T}$ cells concur with the recent report of decreased numbers of FOXP3 + CD3 + regulatory $\mathrm{T}$ cells in decidua in PE (Sasaki et al. 2007). Others have reported that decidual lymphocytes of women with PE produced increased levels of IFNG with reduced levels of IL6 and IL10 indicating cytokine balance dysregulation (Wilczynski et al. 2003).

Double labelling of CD3 + CD56+, CD8 +CD56+ and CD161+CD3 + leucocytes revealed a small population of these double-positive cells in late pregnancy and PE decidua. Lack of TCR V $\alpha 24$ positivity (data not shown) indicates that these double-positive cells probably do not represent an NKT population but rather an activated T-cell population (Pittet et al. 2000). There are no reports to date on the presence or absence of decidual NKT cells in PE, but only $<0.5 \%$ of decidual lymphocytes in normal pregnancy express TCR V $\alpha 24$ (Tsuda et al. 2001). The failure to detect decidual NKT cells in normal pregnancy may reflect the relative insensitivity of immunohistochemistry compared with flow cytometry as well as their low frequency. The small population of CD8+CD56+ cells was reduced in PE. Recently, distinct CD8 $+\mathrm{T}$ cell populations have been shown to display differential cytolytic ability (Pittet et al. 2000, Ohkawa et al. 2001) with CD8 + CD56+T cells 
Table 2 Clinical details of subject groups.

\begin{tabular}{lccc}
\hline & Normal third trimester & PE $^{\mathrm{a}}$ & FGR \\
\hline Number of subjects & 12 & 12 & 8 \\
Gestational age (weeks) (range) & $37.0( \pm 1.0)(26-38)$ & $34.2( \pm 1.3)^{*}(27-41)$ & $34.1( \pm 2.5)(31-38)$ \\
Birth weight (kg) & $3.14( \pm 0.23)$ & $2.23( \pm 0.33)^{*}$ & $1.34( \pm 0.38)^{\dagger}$ \\
Systolic blood pressure (mmHg) & $115.8( \pm 3.1)$ & $156.7( \pm 3.4)^{\dagger}$ & $120.6( \pm 7.7)$ \\
Diastolic blood pressure (mmHg) & $69.2( \pm 2.1)$ & $103.7( \pm 2.0)^{\dagger}$ & $70.6( \pm 7.7)$ \\
Proteinuria (g/24 h) & & $2.5( \pm 0.7)$ & $388( \pm 23)$ \\
Urate $(\mathrm{mmol} / \mathrm{l})$ & & $152( \pm 19)$ & \\
Platelets $\left(\times 10^{\mathrm{b}} / \mathrm{l}\right)$ & & & \\
\hline
\end{tabular}

${ }^{*} P<0.05$ compared with control third trimester pregnancy group. ${ }^{+} P<0.001$ compared with control third trimester pregnancy group.

${ }^{a}$ Eight percent (one subject) also had FGR. ${ }^{b} n=10$. PE defined by International Society for Study of Hypertension in Pregnancy (ISSHP) criteria. Data expressed as mean and \pm s.D.

showing increased cytolytic activity. The significance of their reduced presence in PE is unclear.

Although small populations of B lymphocytes have been reported in decidua (Hussein et al. 2009), this study focused on the major cytotoxic lymphocyte populations, and due to the relative scarcity of decidual B lymphocytes we did not include these in our study.

The difference in gestational age between PE and control group is a potential limitation of this study. However, due to the earlier gestational age of delivery, before 34 weeks for women with early onset PE, this was unavoidable. The groups were matched for gestational age as closely as possible and it is in our opinion that the large difference in leucocyte numbers between PE and late pregnancy decidua represents a true finding, and is not due to the earlier age of PE samples.

In summary, the present findings indicate that both PE and FGR are associated with a reduction in specific decidual leucocyte subpopulations, particularly CD56 + uNK cells. These changes, through alterations in local cytokine and vasoactive mediators, may be implicated in the failure of spiral artery transformation and consequent vasoconstriction, which are characteristic of severe PE and FGR.

\section{Materials and Methods}

\section{Subjects and sample collection}

Placental bed biopsies were performed on 12 healthy women with no hypertension or FGR undergoing elective Caesarean section due to breech presentation or previous Caesarean section, 8 women with FGR without maternal hypertension and
12 women with PE undergoing Caesarean section in the third trimester of pregnancy, as described previously (Robson et al. 2002). None of the subjects was in labour. Placental bed biopsies contained interstitial trophoblast and at least one spiral artery. PE was defined as pregnancy-induced hypertension (systolic blood pressure $\geq 140 \mathrm{mmHg}$ and/or diastolic blood pressure $\geq 90 \mathrm{mmHg}$ after gestational week 20) and proteinuria $(\geq 300 \mathrm{mg} / 24 \mathrm{~h})$ in women with no other underlying medical disease (Brown et al. 2001). FGR was defined ultrasonically as foetal abdominal circumference $(A C)<10$ th centile with a decrease in AC SDS of $>1.5$ SDS and umbilical artery pulsatility index $>95$ th centile (Robson \& Chang 1995). One subject (8\%) in the PE group also had FGR. Gestational age was matched as closely as possible between subject groups, but the gestational age for the control group was higher than that for PE and FGR groups. Gestational age was significantly lower in the PE group than the control group $(P<0.05)$.

Clinical details of the study groups are shown in Table 2 . The study was approved by the Newcastle and North Tyneside Joint Ethics Committee and written consent was obtained from all women.

Tissue samples $\left(5-10 \mathrm{~mm}^{3}\right)$ were snap-frozen in liquid nitrogen-cooled isopentane and stored at $-70^{\circ} \mathrm{C}$. Cryostat serial sections $(7 \mu \mathrm{m})$ were air-dried overnight, fixed for $10 \mathrm{~min}$ in acetone at room temperature, air-dried overnight and stored wrapped at $-20^{\circ} \mathrm{C}$.

\section{$m A b$}

Five murine mAbs were employed for immunostaining of frozen sections (Table 3). The optimal dilution for each mAb was determined in positive control tissue (frozen sections of

Table 3 Primary mAbs

\begin{tabular}{|c|c|c|c|c|}
\hline mAb & Specificity & Clone & Supplier & Dilution \\
\hline CD3 & T cells & UCHT1 & Novocastra $^{a}$ & $1: 200$ \\
\hline CD8 & Cytotoxic T cells, small population of NK cells & DK25 & Dako $^{\mathrm{b}}$ & $1: 100$ \\
\hline CD14 & Macrophages, monocytes & UCHM1 & Serotec $^{\mathrm{c}}$ & $1: 20$ \\
\hline CD56(NCAM1) & NK cells (including uNK cells), small population of cytotoxic T cells & ERIC1 & Novocastra & $1: 100$ \\
\hline CD161(KLRB1C) & $\begin{array}{l}\text { C-type lectin expressed by NK, NKT and T cells. CD161 + cells } \\
\text { represent activated T cells }\end{array}$ & B199.2 & Serotec & $1: 100$ \\
\hline
\end{tabular}

${ }^{\mathrm{a}}$ Novocastra Laboratories Ltd, Newcastle-upon-Tyne, UK. ${ }^{\mathrm{b}}$ Dako Ltd, Ely, UK. ${ }^{\mathrm{c}}$ Serotec Ltd, Kidlington, Oxford, UK. 
either tonsil or normal early pregnancy decidua), and was selected on the basis of maximal specific reactivity and minimal background staining.

\section{Single immunohistochemical labelling}

Single immunohistochemical labelling was performed using an avidin-biotin complex (ABC) method (Vectastain Elite, Vector Laboratories, Peterborough, UK). Sections were rehydrated in $0.05 \mathrm{M}$ Tris-buffered $0.15 \mathrm{M}$ saline ( $\mathrm{pH} 7.6$ (TBS)) for $5 \mathrm{~min}$, followed by incubation for $10 \mathrm{~min}$ with the supplied normal horse blocking serum to block non-specific binding sites. Slides were then incubated sequentially with appropriately diluted primary $\mathrm{mAb}$ (30 min), biotinylated horse anti-mouse immunoglobulins (30 min) and the Vectastain ABC-peroxidase reagent (30 $\mathrm{min})$. The reaction was developed using $3,3^{\prime}$ diaminobenzidine (Sigma Chemical Co.) to give a brown reaction product. Sections were counterstained with Mayer's haematoxylin, blued in Scott's tap water, dehydrated, cleared and mounted in DPX synthetic resin (BDH, Poole, UK). Positive and negative (test sections in which the primary mAb was replaced by normal serum) controls were included in each immunostaining run and for each mAb.

\section{Double immunohistochemical labelling}

Due to the co-expression of CD8 and CD56 by both cytotoxic T-lymphocytes and NK cells (Pittet et al. 2000), and the identification of CD3 + CD56 + CD161 + NKT cells in human decidua (Tsuda et al. 2001), double immunohistochemical labelling was undertaken to characterise further the decidual leucocyte populations in control third trimester and PE samples. Sections were first labelled for CD3, CD8 or CD161 (30 min, except CD161, which was incubated overnight in a humid chamber at $4{ }^{\circ} \mathrm{C}$ ) using the $\mathrm{ABC}$-peroxidase method described above. The reaction was developed using NovaRed (Vector Laboratories) to give a red reaction product. The slides were then washed in TBS for 5 min, overlain with normal rabbit serum diluted 1:10 and incubated for $30 \mathrm{~min}$ with the second primary antibody, CD56, CD3 or CD8. Sections were then sequentially incubated with rabbit-anti-mouse immunoglobulins (Dako, Ely, UK; $30 \mathrm{~min}$ ) and alkaline phosphatase antialkaline phosphatase (APAAP; Dako; $30 \mathrm{~min}$ ). The reaction was developed with alkaline phosphatase substrate III kit (Vecta Blue; (Vector Laboratories) to give a blue reaction product and the reaction was terminated by washing in water. Slides were mounted in Supermount (BioGenex, San Ramon, CA, USA), air-dried overnight and then permanently mounted with DPX.

\section{Quantification and analysis of results}

Positive cells were counted in five randomly selected medium power $(\times 250)$ fields using a $10 \times 10 \mathrm{~mm}$ graticule. Counting was performed in equivalent fields in serial sections from each case for each $\mathrm{mAb}$; fields containing large glands and vessels were excluded. The mean (S.E.M.) number of positive labelled cells per $\times 250$ field was calculated for each cell population.
When counting double-labelled slides, both single-positive (red for first antibody, blue for second antibody) and doublepositive cells (both blue and red) were counted. Data on cell counts were normally distributed and results were compared using Student's $t$-test. Differences were considered to be statistically significant at $P<0.05$.

\section{Declaration of interest}

The authors declare that there is no conflict of interest that could be perceived as prejudicing the impartiality of the research reported.

\section{Funding}

This work was supported by Action Medical Research and an Edmund Harker Foundation studentship.

\section{Acknowledgements}

We are grateful to patients and staff for their assistance in collecting samples.

\section{References}

Ashkar AA, DiSanto JP \& Croy BA 2000 Interferon $\gamma$ contributes to initiation of uterine vascular modification, decidual integrity, and uterine natural killer cell maturation during normal murine pregnancy. Journal of Experimental Medicine 192 259-269.

Bachmayer N, Rafik Hamad R, Liszka L, Bremme K \& SverremarkEkstrom E 2006 Aberrant uterine natural killer (NK)-cell expression and altered placental and serum levels of the NK-cell promoting cytokine interleukin-12 in pre-eclampsia. American Journal of Reproductive Immunology 56 292-301.

Brosens I \& Renaer M 1972 On the pathogenesis of placental infarcts in preeclampsia. Journal of Obstetrics and Gynaecology of the British Commonwealth 79 794-799.

Brown MA, Lindheimer MD, de Swiet M, Van Assche A \& Mountquin J-M 2001 The classification and diagnosis of the hypertensive disorders of pregnancy: statement from the International Society for the Study of Hypertension in Pregnancy (ISSHP). Hypertension in Pregnancy 20 ix-xiv.

Bulmer JN, Morrison L \& Smith JC 1988 Expression of class II MHC gene products by macrophages in human uteroplacental tissue. Immunology $63707-714$.

Bulmer JN, Morrison L, Longfellow M, Ritson A \& Pace D 1991 Granulated lymphocytes in human endometrium: histochemical and immunohistochemical studies. Human Reproduction 6 791-798.

Burk MR, Troeger C, Brinkhaus R, Holzgreve W \& Hahn S 2001 Severely reduced presence of tissue macrophages in the basal plate of preeclamptic placentae. Placenta 22 309-316.

Craven CM, Morgan T \& Ward K 1998 Decidual spiral artery remodelling begins before cellular interaction with cytotrophoblasts. Placenta 19 241-252.

Eide IP, Rolfseng T, Isaksen CV, Mecsei R, Roald B, Lydersen S, Salvesen KA, Harsem NK \& Austgulen R 2006 Serious foetal growth restriction is associated with reduced proportions of natural killers cells in decidua basalis. Virchows Archiv 448 269-276.

Guimond MJ, Wang B \& Croy BA 1998 Engraftment of bone marrow from severe combined immunodeficient (SCID) mice reverses the reproductive deficits in natural killer cell-deficient tge26 mice. Journal of Experimental Medicine 187 217-223.

Haddad EK, Duclos AJ \& Baines MG 1995 Early embryo loss is associated with local production of nitric oxide by decidual mononuclear cells. Journal of Experimental Medicine 182 1143-1151. 
Haller H, Radillo O, Rukavina D, Tedesco F, Candussi G, Petrovic O \& Randic L 1993 An immunohistochemical study of leucocytes in human endometrium, first and third trimester basal decidua. Journal of Reproductive Immunology 23 41-49.

Hampson J, McLaughlin PJ \& Johnson PM 1993 Low-affinity receptors for tumour necrosis factor- $\alpha$, interferon- $\gamma$ and granulocyte-macrophage colony-stimulating factor are expressed on human placental syncytiotrophoblast. Immunology 79 485-490.

Hanna J, Goldman-Wohl D, Hamani Y, Avraham I, Greenfield C, Natanson-Yaron S, Prus D, Cohen-Daniel L, Arnon TI, Manaster I et al. 2006 Decidual NK cells regulate key developmental processes at the human fetal-maternal interface. Nature Medicine 12 1065-1074.

Houlihan JM, Biro PA, Harper HM, Jackson HJ \& Holmes CH 1995 The human amnion is a site of MHC class $\mathrm{lb}$ expression: evidence for the expression of HLA-E and HLA-G. Journal of Immunology 154 5665-5674.

Hu Y, Dutz JP, MacCalman CD, Yong P, Tan R \& von Dadelszen P 2006 Decidual NK cells alter in vitro first trimester extravillous cytotrophoblast migration: a role for IFN- $\gamma$. Journal of Immunology 177 8522-8530.

Hussein MR, Abd-Elwahed AR, Abodeif ES \& Abdulwahed SR 2009 Decidual immune cell infiltrate in hydatidiform mole. Cancer Investigation 27 60-66.

Hutter H, Hammer A, Blaschitz A, Hartmann M, Ebbesen P, Dohr G, Ziegler A \& Uchanska-Ziegler B 1996 Expression of HLA class I molecules in human first trimester and term placenta trophoblast. Cell and Tissue Research 286 439-447.

Khong TY 1987 Immunohistologic study of the leucocytic infiltrate in maternal uterine tissues in normal and pre-eclamptic pregnancies at term. American Journal of Reproductive Immunology and Microbiology $151-8$.

Khong TY, De Wolf F, Robertson WB \& Brosens I 1986 Inadequate vascular responses to placentation in pregnancies complicated by pre-eclampsia and by small-for- gestational age infants. British Journal of Obstetrics and Gynaecology 93 1049-1059.

Kim JS, Romero R, Cushenberry E, Kim YM, Erez O, Nien JK, Yoon BH, Espinoza J \& Kim CJ 2007 Distribution of CD14+ and CD68+ macrophages in the placental bed and basal plate of women with preeclampsia and preterm labour. Placenta 28 571-576.

King A \& Loke YW 1991 On the nature and function of human uterine granular lymphocytes. Immunology Today 12 432-435.

King A, Boocock C, Sharkey AM, Beretta A, Siccardi AG, Loke YW \& Gardner L 1996 Evidence for the expression of HLA-C class I mRNA and protein by human first trimester trophoblast. Journal of Immunology $\mathbf{1 5 6}$ 2068-2076.

Klentzeris LD, Bulmer JN, Warren A, Morrison L, Li T-C \& Cooke ID 1992 Endometrial lymphoid tissue in the timed endometrial biopsy: morphometric and immunohistochemical aspects. American Journal of Obstetrics and Gynecology 167 667-674.

Kurman RJ, Main CS \& Chen HC 1984 Intermediate trophoblast: a distinctive form of trophoblast with specific morphological, biochemical and functional features. Placenta 5 349-369.

Lash GE, Schiessl B, Kirkley M, Innes BA, Cooper A, Searle RF, Robson SC \& Bulmer JN 2006a Expression of angiogenic growth factors by uterine natural killer cells during early pregnancy. Journal of Leukocyte Biology 80 572-580.

Lash GE, Otun HA, Innes BA, Kirkley M, Dr Oliveira L, Searle RF, Robson SC \& Bulmer JN 2006b Interferon-gamma inhibits extravillous trophoblast cell invasion by a mechanism that involves both changes in apoptosis and protease levels. FASEB Journal 20 2512-2518.

Li XF, Charnock-Jones S, Zhang E, Hiby S, Malik S, Day K, Licence D, Bowen JM, Gardner L, King A et al. 2001 Angiogenic growth factor messenger ribonucleic acids in uterine natural killer cells. Journal of Clinical Endocrinology and Metabolism 86 1823-1834.

Lockwood CJ, Matta P, Krikun G, Koopman LA, Masch R, Toti P, Arcuri F, Huang ST, Funai EF \& Schatz F 2006 Regulation of monocyte chemoattractant protein-1 expression by tumour necrosis factor-alpha and interleukin-1 beta in first trimester human decidual cells: implications for pre-eclampsia. American Journal of Pathology 168 445-452.

Nunokawa Y \& Tanaka S 1992 Interferon- $\gamma$ inhibits proliferation of rat vascular smooth muscle cells by nitric oxide generation. Biochemical and Biophysical Research Communications 188 409-415.
Ohkawa T, Seki S, Dobashi H, Koike Y, Habu Y, Ami K, Hiraide H \& Sekine I 2001 Systematic characterization of human CD8 + T cells with natural killer cell markers in comparison with natural killer cells and normal CD8 + T cells. Immunology 103 281-290.

Phillips TA, Ni J, Pan G, Ruben SM, Wei YF, Pace JL \& Hunt JS 1999 TRAIL(Apo-2L) and TRAIL receptors in human placentas: implications for immune privilege. Journal of Immunology 162 6053-6059.

Pijnenborg R, Robertson I, Brosens I \& Dixon G 1981 Trophoblast invasion and the establishment of haemochorial placentation in man and laboratory animals. Placenta 2 71-92.

Pijnenborg R, Anthony J, Davey DA, Rees A, Tiltman A, Vercruysse L \& Van Assche A 1991 Placental bed spiral arteries in the hypertensive disorders of pregnancy. British Journal of Obstetrics and Gynaecology 98 648-655.

Pijnenborg R, Vercruysse L \& Hanssens M 2006 The uterine spiral arteries in human pregnancy: facts and controversies. Placenta 27 939-958.

Pittet MJ, Speiser DE, Valmori D, Cerottini JC \& Romero P 2000 Cutting edge: cytolytic effector function in human circulating CD8+T cells closely correlates with CD56 surface expression. Journal of Immunology 164 1148-1152.

Redline RW 2001 Macrophages in the basal plate of pre-eclamptic placentae. Placenta 22 890-893.

Reister F, Frank HG, Heyl W, Kosanke G, Huppertz B, Schroder W, Kaufmann P \& Rath W 1999 The distribution of macrophages in spiral arteries of the placental bed in pre-eclampsia differs from that in healthy patients. Placenta 20 229-233.

Reister F, Frank HG, Kingdom JCP, Heyl W, Kaufmann P, Rath W \& Huppertz B 2001 Macrophage-induced apoptosis limits endovascular trophoblast invasion in the uterine wall of pre-eclamptic women. Laboratory Investigation 81 1143-1152.

Robson SC \& Chang TC 1995 Measurement of human fetal growth. In Fetus and Neonate, pp 297-325. Eds MA Hanson, JAD Spencer \& CH Rodeck. Cambridge: Cambridge University Press.

Robson SC, Simpson H, Ball E, Lyall F \& Bulmer JN 2002 Punch biopsy of the human placental bed. American Journal of Obstetrics and Gynecology 187 1349-1355.

Saito S 2000 Cytokine network at the feto-maternal interface. Journal of Reproductive Immunology 47 87-103.

Saito N, Pulford KA, Breton-Gorius J, Masse JM, Mason DY \& Cramer EM 1991 Ultrastructural localization of the CD68 macrophage-associated antigen in human blood neutrophils and monocytes. American Journal of Pathology 139 1053-1059.

Saito S, Nishikawa K, Morii T, Enomoto M, Narita N, Motoyoshi K \& Ichijo M 1993 Cytokine production by CD16-CD56 bright natural killer cells in the human early pregnancy decidua. International Immunology $\mathbf{5}$ 559-563.

Sasaki Y, Darmochwal-Kolarz D, Suzuki D, Sakai M, Ito M, Shima T, Shiozaki A, Rolinski J \& Saito $\mathbf{S} 2007$ Proportion of peripheral blood and decidual $\mathrm{CD} 4(+) \mathrm{CD} 25$ (bright) regulatory $\mathrm{T}$ cells in pre-eclampsia. Clinical and Experimental Immunology 149 139-145.

Sharkey AM, Charnock-Jones DS, Boocock CA, Brown KD \& Smith SK 1993 Expression of mRNA for vascular endothelial growth factor in human placenta. Journal of Reproduction and Fertility 99 609-615.

Sindram-Trujillo AP, Scherjon SA, van Hulst-van Miert PP, van Schip JJ, Kanhai HH, Roelen DL \& Claas FHJ 2003 Differential distribution of NK cells in decidua basalis compared with decidua parietalis after uncomplicated human pregnancy. Human Immunology $\mathbf{6 4}$ 921-929.

Smythies LE, Sellers M, Clements RH, Mosteller-Barnum M, Meng G, Benjamin WH, Orenstein JM \& Smith PD 2005 Human intestinal macrophages display profound inflammatory anergy despite avid phagocytic and bacteriocidal activity. Journal of Clinical Investigation 115 66-75.

Stallmach T, Hebisch G, Joller-Jemelka HI, Orban P, Schwaller J \& Engelmann M 1995 Cytokine production and visualized effects in the feto-maternal unit. Laboratory Investigation 73 384-392.

Stallmach T, Hebisch G, Orban P \& Lu X 1999 Aberrant positioning of trophoblast and lymphocytes in the feto-maternal interface with preeclampsia. Virchows Archiv 434 207-211. 
Tsuda H, Sakai M, Michimata T, Tanebek K, Hayakawa S \& Saito S 2001 Characterisation of NKT cells in human peripheral blood and decidual lymphocytes. American Journal of Reproductive Immunology $\mathbf{4 5}$ 295-302.

Vargas ML, Santos JL, Ruiz C, Montes MJ, Aleman P, Garcia-Tortosa C \& Garcia-Olivares E 1993 Comparison of the proportions of leukocytes in early and term human decidua. American Journal of Reproductive Immunology 29 135-140.

Wilczynski JR, Tchorzewski H, Banasik M, Glowacka E, Wieczorek A, Lewkowicz P, Malinowski A, Szpakowski M \& Wilczynski J 2003 Lymphocyte subset distribution and cytokine secretion in third trimester decidua in normal pregnancy and pre-eclampsia. European Journal of Obstetrics, Gynecology, and Reproductive Biology 109 8-15.
Yallampalli C \& Garfield RE 1993 Inhibition of nitric oxide synthesis in rats during pregnancy produces signs similar to those of preeclampsia. American Journal of Obstetrics and Gynecology 169 1316-1320.

Yeh IT, O'Connor DM \& Kurman RJ 1991 Intermediate trophoblast: further immunocytochemical characterization. Modern Pathology 3 282-287.

Received 6 January 2009

First decision 9 February 2009

Revised manuscript received 25 March 2009

Accepted 8 April 2009 